\title{
PROYEK DESAIN REKAYASA DALAM PEMBELAJARAN IPA UNTUK MENINGKATKAN COLLABORATIVE PROBLEM SOLVING DAN PEMAHAMAN KONSEP
}

\author{
F. Nuraeni ${ }^{1 *}$, Z. N. Zahra ${ }^{2}$ \\ ${ }_{1,2}$ Program Studi Pendidikan Guru Sekolah Dasar Universitas Pendidikan Indonesia, Purwakarta, \\ Indonesia \\ *Corresponding Author: fitrinuraeni@upi.edu
}

DOI: 10.24929/lensa.v11i2.162

Received: 13 April 2021

Revised: 9 Oktober 2021

Accepted: 9 Oktober 2021

\begin{abstract}
ABSTRAK
Keterampilan Collaborative Problem Solving (CPS) merupakan suatu keterampilan abad 21 yang dianggap penting. Keterampilan CPS dapat dikembangkan melalui pembelajaran berbasis proyek. Namun dalam implementasinya, guru dan siswa sering mengalami berbagai kesulitan. Salah satu strategi untuk menyiasati hal tersebut adalah dengan mengintegrasikan kegiatan rekayasa. Melalui metode analisis deskriptif, penelitian ini mengungkap bagaimana Proyek Desain Rekayasa, yaitu pembelajaran yang mengintegrasikan engineering design dan pembelajaran berbasis proyek, mampu mengembangkan keterampilan CPS dan meningkatkan pemahaman konsep siswa. Empat belas orang siswa kelas delapan terlibat sebagai subjek penelitian, dimana siswa melakukan sebuah proyek untuk memecahkan suatu masalah secara berkolaborasi melalui aktivitas perekayasaan. Keterampilan kolaborasi siswa diukur melalui observasi selama pembelajaran berlangsung. Sedangkan, kemampuan siswa dalam pemecahanan masalah serta pemahaman konseptual siswa diukur dengan menggunakan pre-test dan post-test. Hasil penelitian menunjukkan bahwa Proyek Desain Rekayasa mampu memfasilitasi siswa untuk mengembangkan keterampilan collaborative problem-solving serta meningkatkan pemahaman konsep siswa mengenai sistem peredaran darah pada manusia.
\end{abstract}

Kata kunci: collaborative problem solving; pemahaman konsep; desain rekayasa.

\begin{abstract}
One of the essential 21st-century skills is Collaborative Problem Solving (CPS) skills. CPS skills can be developed through project-based learning. However, in its implementation, teachers and students often experience various difficulties. One strategy to overcome this is by integrating engineering activities. Through the descriptive analysis method, this research reveals how integrating engineering design and project-based learning, referred to as the Engineering Design Project, can increase CPS skills and students' conceptual understanding. Fourteen eighth-grade students participated in the lesson, where students worked on a project to solve problems collaboratively through engineering activities. Direct observation during learning is done to measure student collaboration skills. Students' problem-solving skills and conceptual understanding were captured using the test prior to and after the implementation of the lesson with Engineering Design Project. The results imply that the Engineering Design Project was able to facilitate students to develop collaborative problem-solving skills as well as improve students' conceptual understanding of the human circulatory system.
\end{abstract}

Keywords: collaborative problem solving; concept understanding; engineering design. 


\section{PENDAHULUAN}

Dewasa ini pendidikan sekolah di berbagai negara mengacu pada pengembangan keterampilan untuk menghadapi tantangan abad 21. Begitu pun di Indonesia seperti tertuang pada revisi dokumen Kurikulum 2013 (Kemendikbud, 2017). Artinya, selain membantu mengembangkan keterampilan yang diperlukan untuk bekerja, pendidikan sekolah juga harus mampu mengembangkan keterampilan hidup siswa untuk bisa sukses di masa mendatang baik sebagai individu maupun sebagai warga negara. Keterampilan inilah yang disebut sebagai keterampilan abad 21 (Griffin, McGraw, dan Care 2015). Salah satu keterampilan abad 21 yang esensial menurut Assessment and Teaching $21^{\text {st }}$ Century Skills (ATC21S) adalah keterampilan collaborative problem-solving yang merupakan kombinasi dari keterampilan berpikir kritis, pengambilan keputusan, pemecahan masalah, dan kemampuan berkolaborasi (Griffin, dkk, 2015).

Pembelajaran berbasis proyek dipercaya sebagai suatu pendekatan pedagogi yang mampu mengembangkan keterampilan collaborative problem solving (Häkkinen, dkk, 2016). Pembelajaran berbasis proyek dianggap sebagai cara efektif untuk meningkatkan keterampilan kolaboratif siswa (Baser, Ozden, dan Kaarslan, 2017) dan keterampilan pemecahan masalah siswa (Bell, 2010). Karakteristik pembelajaran berbasis proyek diantaranya adalah adanya kegiatan proyek atau penggunaan proyek sebagai media pembelajarannya (Susanti \& Kurniawan, 2020). Terlebih, pembelajaran inovatif berbasis proyek dengan melibatkan aspek sains, teknologi dan masyarakat dianggap dapat menumbuhkan keterampilan abad 21 seperti keterampilan pemecahan masalah (Wicaksono, 2020). Sayangnya implementasi pembelajaran berbasis proyek tidak selalu mudah baik untuk guru ataupun siswa. Kesulitan tersebut diantaranya muncul dalam hal manajemen waktu (Chin \& Chia, 2005), serta kesulitan dalam mengenalkan aktivitas merancang dan langkah-langkah pemecahan masalah kepada siswa (Hong, Chen, Wong, Hsu, dan Peng, 2012).

Salah satu cara untuk menyiasati kesulitan tersebut adalah melalui kegiatan rekayasa (engineering). Kegiatan rekayasa sangat relevan dengan pembelajaran berbasis proyek dan merupakan dasar yang ideal untuk aktivitas siswa dalam melakukan proyek (Barroso, 2016). Barroso (2016) lebih jauh menjelaskan bahwa dengan menggunakan proses desain rekayasa (engineering design process) siswa akan terbimbing untuk mengeksplorasi solusi terbaik berdasarkan kriteria dan batasan-batasan tertentu. Dengan demikian, dalam menyelesaikan proyek siswa akan terbantu oleh adanya langkah-langkah untuk memecahkan masalah serta lebih fokus untuk memperoleh solusi dari masalah tersebut dengan mengacu pada kriteria dan batasan yang ada. Namun diharapkan kriteria dan batasan yang dirancang oleh guru tidak membatasi kreativitas siswa.

Disamping itu, kegiatan rekayasa dipandang sebagai sarana yang dapat meningkatkan prestasi siswa dan kualitas pembelajaran sains (Yanyan, Zhinan, Menglu, dan Wen, 2016). Siswa cenderung bersemangat dan lebih aktif dalam belajar ketika desain rekayasa digunakan sebagai konteks untuk pembelajaran sains (Marulcu \& Barnett, 2016). Hasil temuan (Hernandez, dkk, 2014) menunjukkan bahwa implementasi desain rekayasa membantu siswa untuk memahami konsep-konsep yang saling berhubungan secara lebih mendalam. Dengan demikian dapat dikatakan bahwa Proyek Desain Rekayasa, yaitu integrasi desain rekayasa kedalam pembelajaran berbasis proyek, diharapkan dapat membantu siswa untuk mengembangkan keterampilan collaborative problem-solving dan meningkatkan pemahaman siswa mengenai konsep sains tertentu.

Keterampilan collaborative problem solving mencakup domain kognitif dan domain sosial (Hesse, dkk, 2015). Griffin, dkk (2015) lebih jauh menjelaskan bahwa kolaborasi (collaboration) sebagai domain sosial adalah aktivitas bekerja sama untuk mencapai tujuan bersama dimana komunikasi, kerja sama dan kemampuan bereaksi adalah unsur pembentuknya. Sedangkan pemecahan masalah (problem solving) sebagai domain kognitif adalah aktivitas dimana siswa sadar akan adanya kesenjangan antara kondisi aktual dengan kondisi yang diinginkan (tujuan) sehingga memotivasi siswa untuk melakukan aktivitas tertentu untuk mencapai tujuan 
tersebut. Dengan demikian keterampilan collaborative problem-solving didefinisikan sebagai aktivitas bersama dimana dua orang atau suatu kelompok kecil melakukan sejumlah langkah-langkah untuk mengubah keadaan yang ada saat ini menjadi suatu keadaan yang diinginkan (Griffin, dkk, 2015).

Berdasarkan kerangka collaborative problem-solving yang dikembangkan oleh ATC21S (Hesse, dkk, 2015), keterampilan dalam domain sosial terdiri dari tiga subketerampilan yaitu partisipasi, pengambilan perspektif dan regulasi sosial seperti terlihat pada Tabel 1. Sedangkan keterampilan dalam domain kognitif terdiri dari dua sub-keterampilan yaitu regulasi tugas serta pembentukan pengetahuan dan keterampilan belajar (Tabel 2).

Tabel 1. Domain sosial Keterampilan CPS

\begin{tabular}{|c|c|c|}
\hline $\begin{array}{c}\text { Sub- } \\
\text { keterampilan }\end{array}$ & Elemen & Indikator \\
\hline \multirow{3}{*}{ Partisipasi } & Aksi & Aktivitas dalam lingkungan \\
\hline & Interaksi & $\begin{array}{l}\text { Berinteraksi dengan anggota kelompok, } \\
\text { mendorong dan merespons kontribusi } \\
\text { anggota kelompok }\end{array}$ \\
\hline & $\begin{array}{l}\text { Penyelesaian } \\
\text { tugas/ketekuna } \\
\mathrm{n}\end{array}$ & $\begin{array}{l}\text { Melakukan dan menyelesaikan tugas } \\
\text { atau bagian dari tugas secara individu }\end{array}$ \\
\hline \multirow{2}{*}{$\begin{array}{l}\text { Pengambilan } \\
\text { perspektif }\end{array}$} & Respons adaptif & $\begin{array}{lrr}\begin{array}{l}\text { Mengabaikan, } \\
\text { mengadaptasi }\end{array} & \begin{array}{r}\text { menerima } \\
\text { kontribusi }\end{array} & \begin{array}{r}\text { atau } \\
\text { anggota }\end{array} \\
\text { kelompok } & & \\
\end{array}$ \\
\hline & $\begin{array}{l}\text { Kesadaran akan } \\
\text { audien }\end{array}$ & $\begin{array}{l}\text { Tahu bagaimana bersikap/bertutur kata } \\
\text { agar sesuai dengan anggota kelompok }\end{array}$ \\
\hline \multirow{4}{*}{ Regulasi sosial } & Negosiasi & $\begin{array}{l}\text { Mencapai kesepakatan bersama atau } \\
\text { berkompromi }\end{array}$ \\
\hline & Metamemori & $\begin{array}{l}\text { Mengenali kekuatan serta kelemahan } \\
\text { diri }\end{array}$ \\
\hline & $\begin{array}{l}\text { Memori } \\
\text { transaktif }\end{array}$ & $\begin{array}{l}\text { Mengenali kekuatan serta kelemahan } \\
\text { anggota kelompok }\end{array}$ \\
\hline & $\begin{array}{l}\text { Inisiatif } \\
\text { tanggung jawab }\end{array}$ & $\begin{array}{l}\text { Bertanggung jawab dan memastikan } \\
\text { kelompok menyelesaikan tugas }\end{array}$ \\
\hline
\end{tabular}

Tabel 2. Keterampilan CPS - domain kognitif

\begin{tabular}{|c|c|c|}
\hline $\begin{array}{c}\text { Sub- } \\
\text { keterampilan }\end{array}$ & Elemen & Indikator \\
\hline \multirow{6}{*}{ Regulasi tugas } & Analisis masalah & $\begin{array}{l}\text { Menganalisis dan mendeskripsikan } \\
\text { masalah dalam bahasa yang mudah } \\
\text { dipahami }\end{array}$ \\
\hline & Tujuan & $\begin{array}{l}\text { Menetapkan tujuan yang jelas dalam } \\
\text { menyelesaikan tugas }\end{array}$ \\
\hline & $\begin{array}{l}\text { Pengelolaan } \\
\text { sumber daya }\end{array}$ & $\begin{array}{l}\text { Mengelola sumber daya atau mengatur } \\
\text { anggota kelompok untuk } \\
\text { menyelesaikan tugas }\end{array}$ \\
\hline & Fleksibilitas & $\begin{array}{l}\text { Menerima situasi yang ambigu (tidak } \\
\text { lazim) }\end{array}$ \\
\hline & $\begin{array}{l}\text { Mengumpulkan } \\
\text { elemen-elemen } \\
\text { informasi }\end{array}$ & $\begin{array}{l}\text { Mengeksplor dan memahami elemen- } \\
\text { elemen tugas }\end{array}$ \\
\hline & Sistematis & $\begin{array}{l}\text { Mengimplementasikan solusi atas } \\
\text { suatu masalah dan memonitor } \\
\text { progresnya }\end{array}$ \\
\hline $\begin{array}{l}\text { Pembentukan } \\
\text { pengetahuan } \\
\text { keterampilan }\end{array}$ & Hubungan & $\begin{array}{l}\text { Mengidentifikasi hubungan dan pola } \\
\text { yang terbentuk diantara elemen } \\
\text { pengetahuan }\end{array}$ \\
\hline
\end{tabular}




\begin{tabular}{|c|c|c|c|}
\hline $\begin{array}{c}\text { Sub- } \\
\text { keterampilan }\end{array}$ & \multicolumn{2}{|c|}{ Elemen } & Indikator \\
\hline \multirow[t]{2}{*}{ belajar } & $\begin{array}{l}\text { Aturan } \\
\text { Akibat }\end{array}$ & Sebab- & $\begin{array}{l}\text { Menggunakan pemahaman sebab dan } \\
\text { akibat untuk mengembangkan suatu } \\
\text { rencana }\end{array}$ \\
\hline & Hipotes & & $\begin{array}{l}\text { Mengadaptasi penalaran atau cara } \\
\text { bertindak ketika ada perubahan } \\
\text { informasi atau keadaan }\end{array}$ \\
\hline
\end{tabular}

Salah satu pendekatan pedagogi yang cocok untuk mengembangkan keterampilan collaborative problem solving adalah melalui pembelajaran berbasis proyek (Häkkinen, dkk, 2016). Mengerjakan proyek secara berkelompok mendorong siswa untuk bernegosiasi dalam memecahkan masalah, menghargai kerja sama dan bertindak sebagai pendengar yang baik bagi anggota kelompok. Dengan demikian siswa mampu mengembangkan keterampilan kolaborasi mereka.

Disamping itu, pembelajaran yang demikian juga dapat melatih keterampilan pemecahan masalah melalui konteks masalah dalam keseharian yang harus dipecahkan, kegiatan menentukan tujuan, merencanakan langkah-langkah untuk mencapainya serta mengelola informasi dan mengimplementasikan beragam strategi belajar. Pengalaman-pengalaman belajar inilah yang kemudian akan membuat siswa tak asing lagi dengan aktivitas pemecahan masalah. Menurut (George Lucas Educational Foundation, 2007) terdapat enam tahapan dalam pembelajaran berbasis proyek yaitu (1) mulai dengan pertanyaan penting atau esensial, (2) merancang rencana proyek, (3) menyusun jadwal proyek, (4) memantau siswa dan progres proyek, dan (5) menilai hasil, serta (6) mengevaluasi pengalaman.

Kegiatan rekayasa merupakan kegiatan yang relevan dengan pembelajaran berbasis proyek karena keduanya mengacu pada masalah atau aplikasi dalam keseharian. Disamping itu kegiatan rekayasa dianggap sebagai dasar yang ideal untuk aktivitas siswa dalam pembelajaran berbasis proyek (Barroso, 2016).

Rekayasa didefinisikan sebagai tindakan yang dilakukan untuk meningkatkan kualitas hidup dengan mengubah dunia sedemikian rupa menggunakan pengetahuan dan observasi (Bagiati \& Evangelou, 2016). Yanyan, dkk (2016) secara lebih spesifik mendefinisikan rekayasa sebagai aplikasi ilmu pengetahuan untuk memecahkan masalah. Dalam studi yang dilakukan oleh (Wendell \& Rogers, 2013), rekayasa secara autentik di deskripsikan sebagai proses merancang dan membuat prototipe suatu solusi untuk suatu masalah. (Guzey, Moore, Harwell, dan Moreno, 2016) menyatakan bahwa bagian utama dalam rekayasa adalah aktivitas merancang yang digunakan oleh para engineer ketika mereka mencoba menciptakan teknologi baru atau memecahkan masalah tertentu. Kegiatan merancang tersebut memerlukan penalaran kognitif, pemodelan mental dan perhitungan yang harus memenuhi kriteria dan batasan tertentu (Lewis dalam Schnittka, dkk, 2016). Dalam pembelajaran sains yang mengintegrasikan kegiatan rekayasa, siswa didorong untuk menggunakan pengetahuan dan pengalaman yang mereka miliki serta mengkomunikasikan apa yang mereka pelajari di akhir pembelajaran (Laboy-Rush, 2010). Han, Capraro, dan Capraro (2014) menyatakan bahwa karakteristik desain rekayasa adalah berpusat pada siswa, interdisipliner, kolaboratif dan berbasis pada teknologi. Aktivitas yang siswa lakukan dalam pembelajaran berbasis desain rekayasa selalu mencakup konstruksi produk fisik sebagai salah satu cara untuk menyelesaikan masalah manusia (Marulcu \& Barnett, 2016; Wendell \& Rogers, 2013). Disamping itu, kegiatan siswa selalu mencakup kegiatan kolaboratif sebagai tim bukan hanya kegiatan individu saja (Wendell \& Rogers, 2013). Namun demikian, desain rekayasa bukan hanya terbatas pada merancang sebuah teknologi untuk memecahkan masalah, tapi diperlukan adanya proses berulang yang membutuhkan pemikiran engineering berdasarkan hukum-hukum dan teori-teori ilmiah (King \& English, 2016).

Dengan demikian, dalam hal kesesuaian pembelajaran berbasis proyek dan desain rekayasa dengan pembelajaran IPA, maka merupakan suatu upaya yang baik untuk mencoba mengimplementasikan proyek desain rekayasa guna meningkatkan capaian belajar siswa dan mengembangkan CPS siswa. Oleh sebab itu, penelitian ini 
bertujuan untuk mengungkap bagaimana Proyek Desain Rekayasa, yaitu pembelajaran yang mengintegrasikan engineering design dan pembelajaran berbasis proyek, mampu mengembangkan keterampilan CPS dan meningkatkan pemahaman konsep siswa.

\section{METODE}

\section{Jenis Penelitian}

Pada penelitian ini digunakan metode analisis deskriptif untuk menjawab masalah penelitian. Analisis deskriptif dapat berdiri sendiri sebagai penelitian yang lengkap, terutama ketika temuan berfokus pada mengidentifikasi fenomena yang tidak terdokumentasi, pola tersembunyi atau mendiagnosis kebutuhan dunia nyata (Loeb, dkk, 2017). Jenis penelitian deskriptif ini dapat digunakan untuk memberikan informasi tentang pemahaman dasar suatu fenomena. Lebih lanjut, Loeb, dkk (2017) menjelaskan bahwa analisis deskriptif dapat digunakan untuk menafsirkan mengapa suatu intervensi menghasilkan atau tidak menghasilkan efek tertentu melalui akses ke rincian deskriptif yang secara akurat dan menyeluruh mencirikan kondisi dan konteks suatu penelitian.

\section{Waktu dan Tempat Penelitian}

Penelitian diselenggarakan pada tanggal 30 Januari hingga 22 Februari tahun 2018 di suatu sekolah swasta di Bandung Barat.

\section{Subjek Penelitian}

Subjek penelitian adalah empat belas siswa kelas delapan pada suatu sekolah swasta di Bandung Barat. Sebelum menjalani pembelajaran dengan Proyek Desain Rekayasa, siswa telah mempelajari tentang sistem peredaran darah tetapi belum mempelajari tentang penyakit pada sistem peredaran darah.

\section{Prosedur Penelitian}

Rangkaian kegiatan dalam Penelitian dilakukan melalui 3 tahapan utama yaitu tahap persiapan, tahap pelaksanaan dan tahap akhir. Langkah pertama yang dilakukan selama persiapan adalah melakukan studi pendahuluan dan analisis kebutuhan. Kegiatan tersebut diselenggarakan dengan menganalisis berbagai hasil penelitian terkait pembelajaran berbasis proyek, desain rekayasa, pemecahan masalah kolaboratif serta analisis cermat terhadap kurikulum sains yang diterapkan di kelas 8 sekolah menengah pertama. Langkah kedua adalah menentukan subjek penelitian dan materi pelajaran yang akan digunakan sebagai konteks pembelajaran. Selanjutnya, seperangkat RPP dirancang berdasarkan langkah-langkah proyek desain rekayasa berkenaan dengan kompetensi dasar yang ada pada Kurikulum Nasional dan kurikulum Cambridge terkini yang digunakan di sekolah bersangkutan. Tahap implementasi dilakukan untuk mendapatkan data yang dibutuhkan, yang meliputi data pelaksanaan pembelajaran dengan proyek desain rekayasa, keterampilan kolaborasi siswa pada pembelajaran sebelumnya dan saat terlibat dalam pembelajaran dengan proyek desain rekayasa, keterampilan pemecahan masalah siswa sebelum belajar melalui proyek desain rekayasa dan setelah mengikuti kegiatan pembelajaran proyek desain rekayasa, serta pemahaman konsep siswa sebelum dan setelah pembelajaran dilaksanakan. Untuk memperoleh informasi mengenai dampak pembelajaran dengan proyek desain rekayasa terhadap keterampilan kolaborasi siswa, maka diperlukan adanya pengukuran keterampilan kolaborasi pada pembelajaran sebelumnya. Oleh karena itu, observasi keterampilan kolaborasi awal siswa dilakukan pada pembelajaran yang melibatkan kegiatan berkelompok pula, yaitu pada saat subjek penelitian melakukan kegiatan praktikum pengujian golongan darah.

\section{Data, Instrumen dan Teknik Pengumpulan Data}

Guna memperoleh data yang diperlukan dalam penelitian dibuatlah beberapa instrumen yang mencakup lembar observasi pelaksanaan pembelajaran, pretest dan posttest untuk mengukur CPS pada domain kognitif, rubrik penilaian CPS pada domain sosial serta tes pemahaman konsep mengenai penyakit dalam peredaran darah manusia. Selanjutnya, instrumen melalui proses trial atau pengujian terlebih dahulu 
sebelum digunakan pada subjek penelitian. Pengujian dilakukan dengan menerapkan pembelajaran di kelas lain yang terdiri dari siswa kelas delapan. Pada saat yang sama, instrumen untuk observasi pelajaran dan rubrik untuk keterampilan kolaborasi juga diuji coba. Di akhir pembelajaran dilakukan pengujian instrumen keterampilan pemecahan masalah dan pemahaman konseptual. Hasil uji coba yang diperoleh digunakan untuk menyempurnakan instrumen penelitian.

CPS domain kognitif, yaitu keterampilan pemecahan masalah diukur melalui pretest dan posttest yang dirancang dengan mengadaptasi kerangka domain kognitif CPS (Hesse, dkk, 2015). Tes ini terdiri dari sembilan pertanyaan terstruktur. Respons siswa pada setiap item dinilai menggunakan rubrik yang diadaptasi dari kerangka CPS pada domain kognitif (Hesse, dkk, 2015). Nilai maksimum untuk setiap elemen keterampilan pemecahan masalah adalah 3 poin yang mengacu pada tingkat keterampilan yang tinggi, sedangkan nilai minimum adalah 1 poin yang mengacu pada tingkat keterampilan yang rendah. Sedangkan CPS domain sosial, yaitu keterampilan kolaborasi diukur menggunakan rubrik observasi yang diadaptasi dari kerangka CPS domain sosial (Hesse, dkk, 2015). Observer mengamati perilaku siswa yang menunjukkan elemen tertentu dalam tiga sub keterampilan kolaborasi. Perilaku tersebut dinilai mulai dari 1 hingga 3 poin. 1 poin mengacu pada level rendah, 2 poin mengacu pada level menengah dan 3 poin mengacu pada level tinggi dari keterampilan kolaborasi. Sementara data pemahaman konsep siswa didapatkan melalui tes pemahaman konsep sebelum dan sesudah pembelajaran di lakukan. Hasil pengujian instrument pemahaman konsep menunjukkan bahwa 12 dari 15 soal dinyatakan valid dan tes memiliki nilai reliabilitas tes sebesar 0.89 atau berada pada kategori sangat tinggi.

\section{Teknik Analisis Data}

Dari berbagai instrument yang telah disebutkan diatas diperoleh data-data penelitian yang kemudian dianalisis menggunakan statistika deskriptif. Hal ini bertujuan untuk melihat rerata nilai siswa pada setiap domain atau aspek yang diukur. Kemudian dilakukanlah perbandingan antara kondisi sebelum dan sesudah memperoleh pembelajaran dengan Proyek Desain Rekayasa.

\section{HASIL DAN PEMBAHASAN}

Pembelajaran menggunakan Proyek Desain Rekayasa pada materi sistem peredaran darah ini berlangsung selama 4 pertemuan. Pertemuan pertama berlangsung selama 1 jam pelajaran. Tujuan pembelajaran untuk pertemuan pertama ini adalah untuk memastikan bahwa siswa memiliki pengetahuan yang cukup untuk melakukan kegiatan rekayasa. Melalui diskusi atau tanya jawab, siswa dibimbing untuk mengingat kembali konsep-konsep terkait sistem peredaran darah pada manusia. Contohnya seperti struktur, fungsi dan mekanisme peredaran darah pada manusia. Kemudian guru memberikan penjelasan mengenai beberapa penyakit dalam peredaran darah pada manusia, dimana salah satunya adalah penyakit jantung koroner yang dianggap sebagai penyakit paling mematikan nomor satu di dunia. Guru kemudian menampilkan perkembangan teknologi dan prosedur yang sudah manusia ciptakan untuk menangani penyakit tersebut. Salah satunya adalah tindakan angioplasti dengan menggunakan kateter. Untuk membantu siswa memahami bagaimana teknologi tersebut masuk ke dalam tubuh manusia guru dapat menampilkan video. Konteks inilah yang kemudian akan digunakan sebagai masalah yang harus siswa selesaikan melalui kegiatan rekayasa.

Pertemuan kedua berlangsung selama 2 jam pembelajaran yang mencakup tahapan mengidentifikasi, menyelidiki, membayangkan, merancang dan membuat jadwal. Diawal pembelajaran, guru membagi siswa menjadi sejumlah kelompok kecil dengan tiga atau empat orang anggota. Kemudian siswa diberi satu set dokumen yang berisi artikel terkait masalah yang akan mereka selesaikan, daftar kriteria dan batasan serta daftar alat dan bahan yang akan guru sediakan. Untuk memudahkan siswa dalam mengidentifikasi dan mengemukakan pernyataan masalah, artikel dirancang sedemikian rupa dalam bentuk skenario sehingga lebih bermakna bagi siswa. Setelah mengidentifikasi masalah yang perlu diselesaikan, siswa dibimbing 
untuk menggali informasi terkait teknologi apa saja yang telah manusia ciptakan untuk mengatasi masalah tersebut dan apa kekurangannya. Dari kekurangan tersebut siswa kemudian membayangkan solusi apa yang mungkin mereka buat. Selanjutnya dengan mempertimbangkan kriteria dan batasan tertentu setiap kelompok menentukan satu solusi terbaik. Kemudian siswa menggambar desain alat yang akan mereka buat. Siswa dibimbing untuk menggambar secara detail dengan memberikan label, dimensi serta menuliskan jumlah alat dan bahan yang akan mereka butuhkah. Pada pembelajaran ini siswa secara implisit diarahkan untuk membuat kateter yang mampu membersihkan plak pada arteri yang tersumbat secara efektif, mudah digunakan dan aman. Untuk menguji alat tersebut setiap kelompok juga diarahkan untuk membuat model arteri yang tersumbat. Gambar 1 menunjukkan contoh desain kateter yang siswa buat.
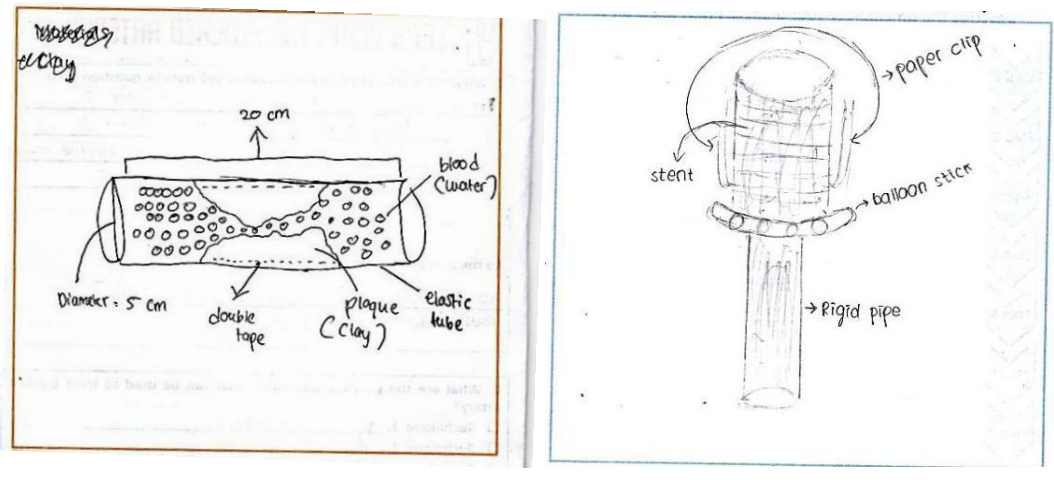

Gambar 1. Desain (a) model arteri dan (b) kateter yang dibuat oleh siswa

Pada tahapan merancang inilah siswa secara aktif merefleksikan pengetahuan yang mereka miliki untuk menentukan alat dan bahan apa yang paling sesuai dan cocok untuk digunakan. Di samping itu, guru perlu mendiskusikan prosedur pengujian alat agar siswa benar-benar paham akan seperti apa alat yang mereka buat dan bagaimana alat tersebut bekerja. Di akhir pembelajaran guru melakukan diskusi kelas untuk secara bersama-sama menentukan jadwal penyelesaian proyek.

Pertemuan ketiga berlangsung selama 2 jam pelajaran yang mencakup tahapan membuat. Di awal pembelajaran, guru membagikan peralatan dan bahan yang akan digunakan oleh setiap kelompok. Alat dan bahan tersebut disesuaikan dengan kebutuhan setiap kelompok berdasarkan rancangan yang telah mereka buat. Kemudian siswa secara mandiri membuat model arteri dan prototipe kateter. Di akhir pembelajaran beberapa kelompok diminta untuk mempresentasikan produk yang telah mereka buat diikuti oleh diskusi terbuka mengenai alasan dibalik desain yang mereka buat. Guru memilih 2 kelompok yang memiliki teknik berbeda. Gambar 2 menunjukkan Contoh model arteri dan prototipe yang siswa buat. Gambar 2a menunjukkan bahwa salah satu kelompok memutuskan untuk menggunakan selang dengan ukuran yang lebih besar dibandingkan kelompok lain Gambar 2b. Di samping itu kelompok tersebut menggunakan balon yang berfungsi untuk menekan plak pada arteri yang tersumbat. Disisi lain kelompok lain menggunakan kawat elastis untuk menghancurkan plak pada arteri yang tersumbat. Hal ini menunjukkan bahwa meskipun seluruh siswa memiliki masalah dan tujuan yang sama namun solusi yang mereka buat bisa saja berbeda. Kriteria dan batasan masalah hendaklah dirancang sedemikian rupa sehingga tidak membatasi kreativitas siswa. Gambar 3 menunjukkan contoh produk yang telah siswa buat. 


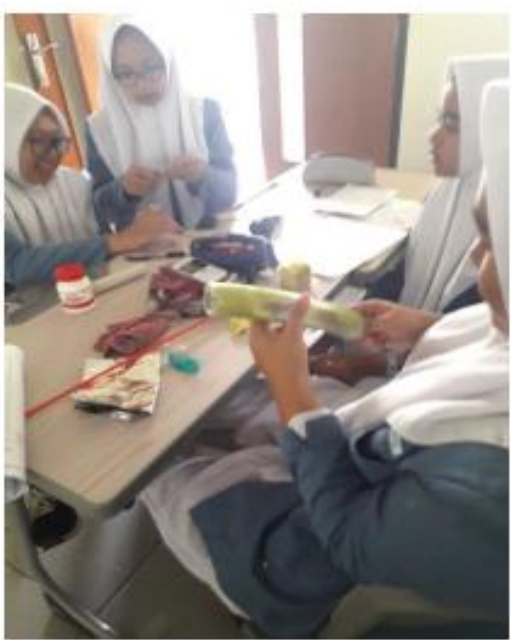

(a)

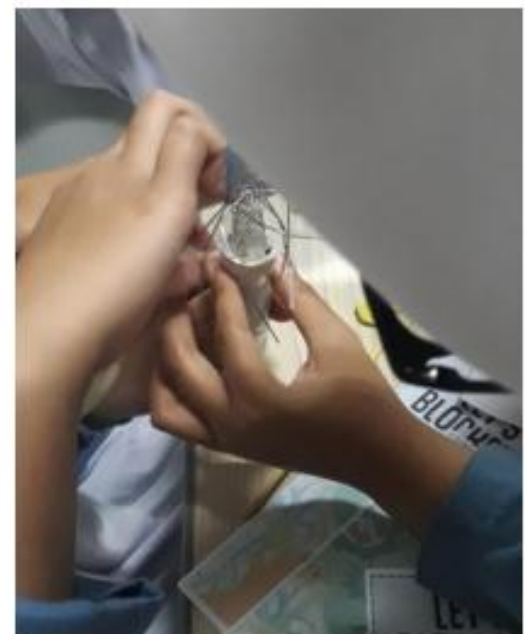

(b)

Gambar 2. Siswa membuat (a) model arteri dan (b) prototipe kateter

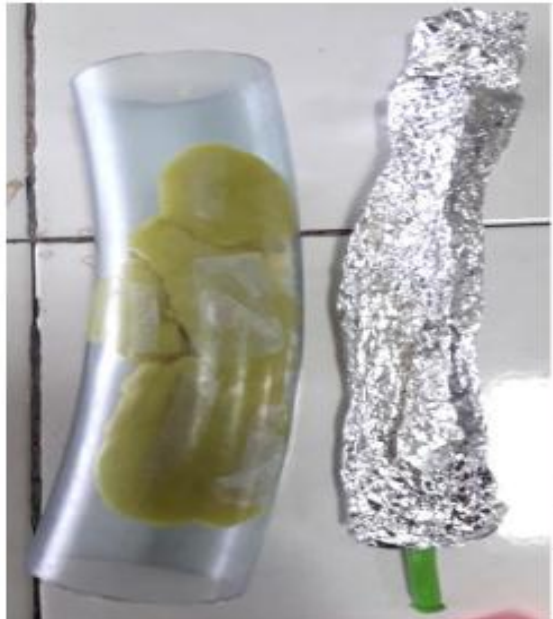

(a)

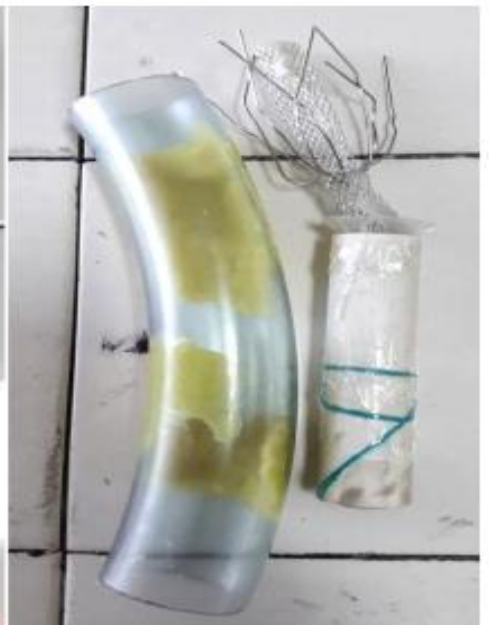

(b)

Gambar 3. Contoh produk yang telah siswa buat

Pertemuan keempat berlangsung selama 2 jam pelajaran yang mencakup tahapan menguji, memperbaiki, mengkomunikasikan dan mengevaluasi pengalaman. Di awal pembelajaran, guru mendemonstrasikan prosedur pengujian alat sebelum setiap kelompok melakukannya secara mandiri. Kemudian setiap kelompok melakukan pengujian alat yang mencakup pengamatan dan pengambilan data. Pengambilan data yang siswa lakukan adalah pengukuran waktu yang dibutuhkan oleh sejumlah darah untuk mengalir melalui arteri yang tersumbat dan waktu yang dibutuhkan oleh sejumlah darah yang sama untuk mengalir melalui arteri yang sudah diberikan tindakan angioplasti menggunakan kateter yang siswa buat sebelumnya seperti yang terlihat di Gambar 4. Dari data tersebut siswa kemudian menghitung dan membandingkan laju aliran darah sebelum dan sesudah tindakan untuk menentukan efektivitas produk atau solusi yang mereka buat. Di samping itu selama pengujian, siswa mengamati dan mengidentifikasi kekurangan dan kelebihan dari produk yang telah mereka buat. Berdasarkan kekurangan dan kelebihan inilah siswa memperbaiki desain agar produk yang dihasilkan mampu memecahkan masalah dengan lebih efektif. Perbandingan perubahan atau perbaikan desain sebelum uji coba dan setelah uji coba dapat dilihat pada Gambar 5. Kemudian masing-masing kelompok mempresentasikan secara singkat perbaikan apa saja yang akan mereka lakukan. Sebelum mengakhiri pembelajaran guru membimbing siswa untuk melakukan evaluasi proyek secara keseluruhan. Evaluasi tersebut mencakup hal penting apa saja yang siswa pelajari, hal apa yang akan mereka lakukan dengan lebih baik, serta bagian 
proyek manakah yang disenangi dan kurang disenangi oleh siswa. Hasil evaluasi ini tentu akan sangat bermanfaat sebagai pertimbangan untuk proyek selanjutnya.

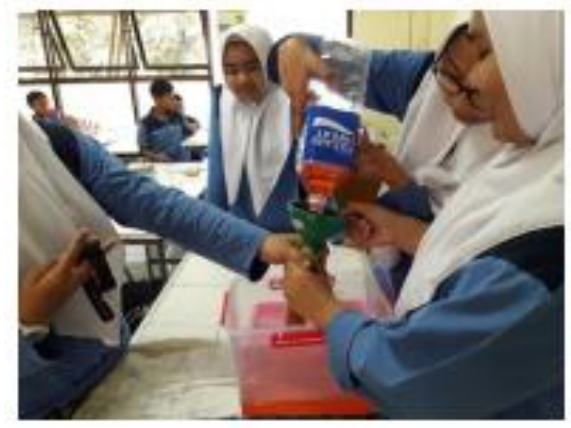

(a)

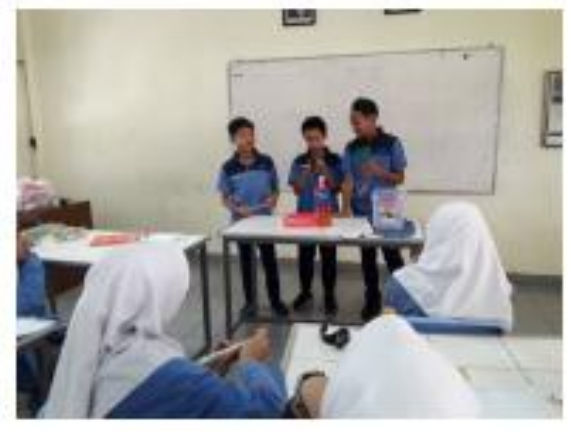

(b)

Gambar 4. (a) Siswa menguji produk (b) siswa melakukan presentasi

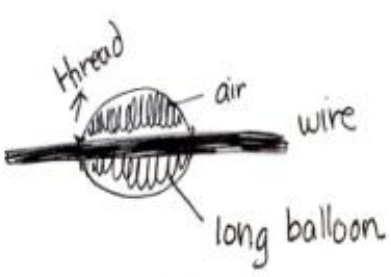

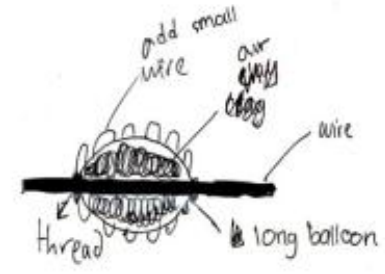

wire $/$ stent $\rightarrow$ to breat plaque

(a)

(b)

Gambar 5. Desain kateter (a) sebelum uji coba (b) setelah uji coba.

Hasil penelitian yang diperoleh melalui observasi selama pembelajaran serta tes sebelum dan sesudah pembelajaran menunjukkan bahwa Proyek Desain Rekayasa mampu memfasilitasi siswa untuk mengembangkan keterampilan collaborative problem solving serta meningkatkan pemahaman konsep mengenai sistem peredaran darah pada manusia.

Pada saat siswa terlibat dalam pembelajaran dengan menggunakan Proyek Desain Rekayasa pada materi peredaran darah tersebut ternyata siswa menunjukkan keterampilan kolaborasi yang lebih baik jika dibandingkan dengan pembelajaran kolaboratif lain, contohnya pembelajaran dengan kegiatan praktikum uji golongan darah secara berkelompok yang dilakukan sebelumnya. Gambar 6 menunjukkan perbandingan rata-rata nilai keterampilan kolaborasi siswa diantaranya kedua pembelajaran tersebut.

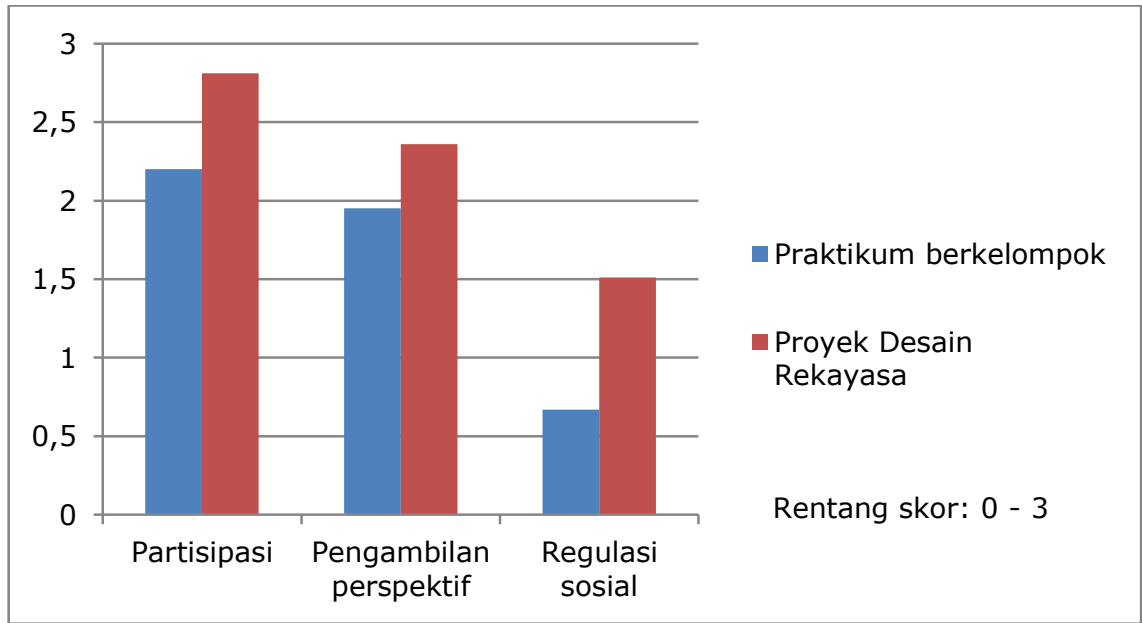

Gambar 6. Perbandingan nilai rata-rata keterampilan kolaborasi 
Melalui pembelajaran yang mengintegrasikan kegiatan desain rekayasa, siswa memiliki banyak kesempatan untuk mengekspresikan ide dan aktif berdiskusi untuk mengeksplorasi fenomena yang sedang mereka pelajari (Moje, Collazo, Carrillo, dan Marx, 2001). Integrasi desain rekayasa juga menempatkan siswa pada situasi dimana mereka dihadapkan dengan ide yang beragam khususnya pada tahapan merancang, membuat dan memperbaiki. Menurut (Lai, DiCerbo, dan Foltz, 2017) agar keterampilan kolaborasi itu muncul, siswa perlu dihadapkan dengan pembelajaran yang memunculkan berbagai perspektif dan perdebatan.

Di samping itu, setelah terlibat dalam Proyek Desain Rekayasa, siswa juga menunjukkan keterampilan pemecahan masalah yang meningkat dibandingkan denngan pembelajaran sebelumnya. Peningkatan nilai rata-rata siswa pada tes pemecahan masalah setelah pembelajaran dapat dilihat pada Gambar 7. Hal ini karena dalam Proyek Desain Rekayasa siswa dilatih untuk menganalisis masalah, mengumpulkan informasi, mengatur tugas dalam kelompok, serta fleksibel atas adanya perbedaan pendapat.

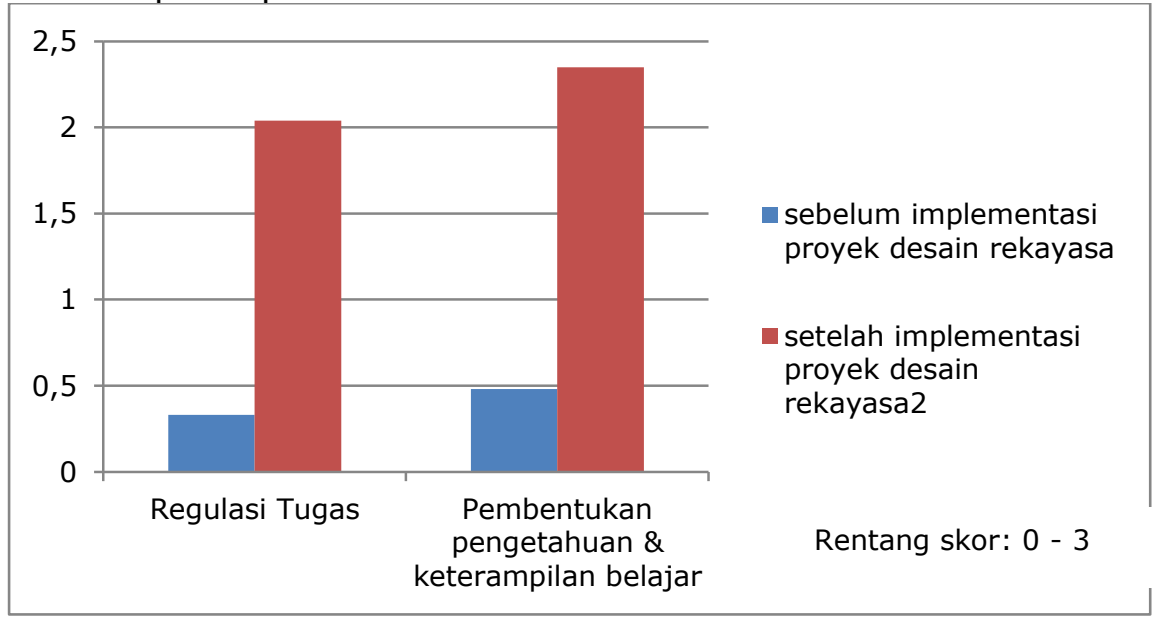

Gambar 7. Perbandingan nilai rata-rata keterampilan pemecahan masalah

Pembelajaran melalui Proyek Desain Rekayasa ini juga mampu meningkatkan pemahaman konsep siswa mengenai sistem peredaran darah pada manusia. Gambar 8 mengilustrasikan adanya peningkatan nilai rata-rata siswa pada tes pemahaman konsep yang mencakup pemahaman konsep pada dimensi proses kognitif $\mathrm{C} 2, \mathrm{C} 3, \mathrm{C} 4$ dan C5.

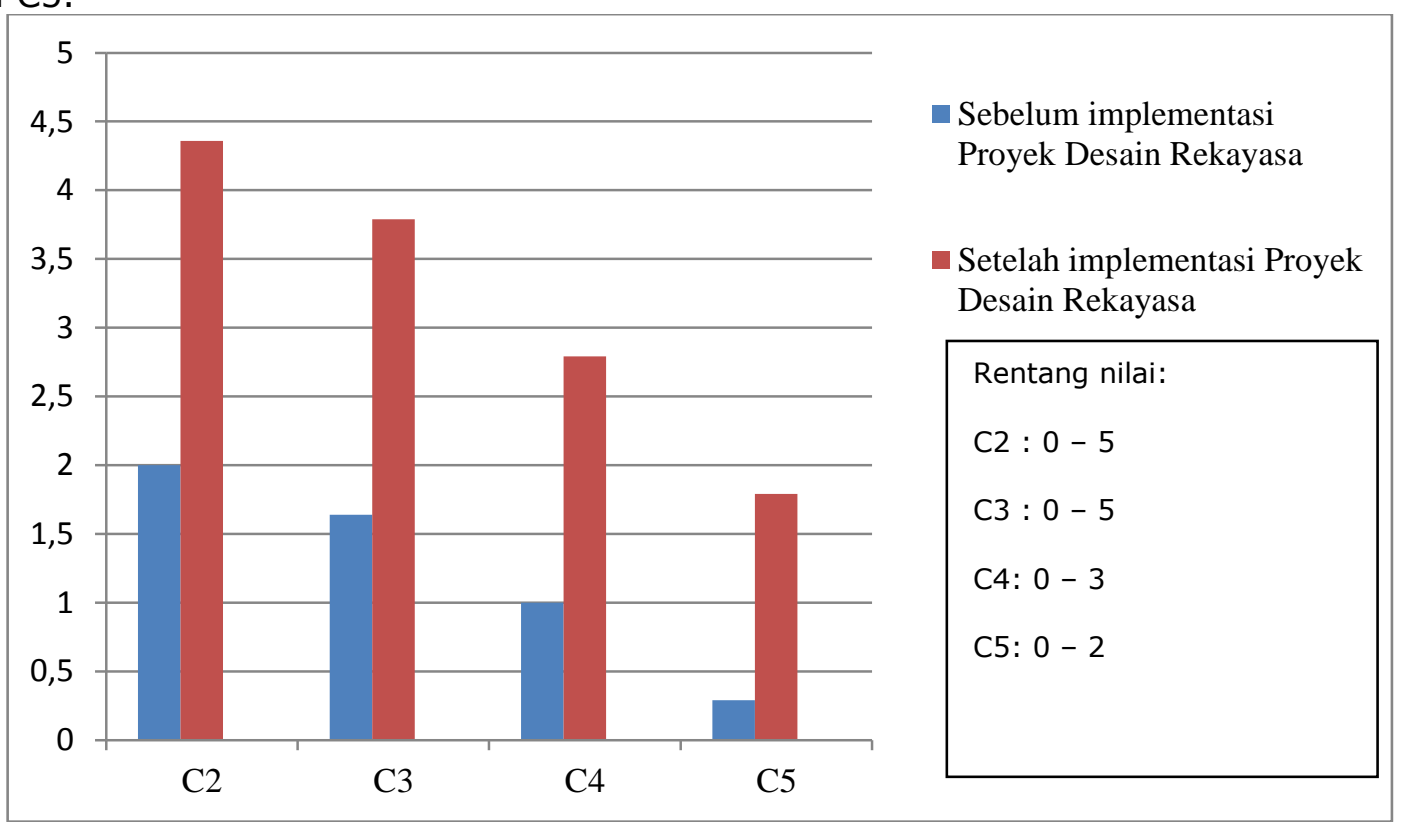

Gambar 8. Perbandingan nilai rata-rata pada dimensi proses kognitif 
Berdasarkan teori konstruktivisme, melalui kegiatan mencipta atau berkreasi siswa akan memperoleh pemahaman yang lebih mendalam (Yanyan, dkk, 2016). Menurut Papert (Schnittka, dkk, 2016) siswa akan mampu mengkonstruk pengetahuan dengan lebih efektif saat mereka aktif mengkonstruk produk dalam konteks dunia nyata. Sedangkan dari sudut pandang konstruktivisme sosial, pembelajaran bukan hanya terjadi di dalam individu namun juga dimediasi oleh interaksi sosial dan kolaborasi dengan teman dan instruktur atau guru (Schnittka, dkk 2016). Hal serupa ditekankan oleh (Wendell \& Rogers 2013) yang menyatakan bahwa kegiatan desain rekayasa dalam pembelajaran sains memungkinkan siswa untuk menyebarkan beban kognitif untuk memahami konsep-konsep sains melalui aktivitas membangun dan interaksi dengan teman bahkan instruktur, mentor atau guru.

\section{KESIMPULAN}

Mengintegrasikan desain rekayasa ke dalam pembelajaran berbasis proyek dapat mendorong siswa untuk memahami konsep-konsep sains dengan lebih baik. Hal ini dikarenakan kegiatan rekayasa dapat memberikan momentum kepada siswa untuk menemukan hubungan antar konsep sains tertentu dan mengaplikasikannya untuk menyelesaikan masalah dalam konteks dunia nyata. Tahapan membuat sangat berkontribusi dalam membantu siswa menggali konsep-konsep tertentu secara lebih mendalam. Di samping itu, adanya interaksi dan komunikasi dengan teman atau guru juga dapat memfasilitasi siswa untuk membangun pemahaman konsep yang lebih komprehensif. Dengan demikian dapat disimpulkan bahwa pembelajaran sains dengan desain rekayasa mampu memberikan peluang bagi siswa untuk bekerja secara kolaboratif dalam memecahkan masalah. Untuk memecahkan masalah tersebut siswa perlu melakukan langkah-langkah tertentu dengan mengaplikasikan hukum-hukum dan teori-teori ilmiah yang mereka pelajari sehingga pemahaman konsep mengenai materi yang dipelajari akan semakin meningkat.

\section{SARAN}

Temuan pada studi ini diharapkan mampu memberikan gambaran mengenai peluang implementasi pembelajaran berbasis proyek yang diintegrasikan dengan aktivitas desain rekayasa pada materi IPA lainnya untuk membantu siswa mengembangkan keterampilan collaborative problem solving. Disamping itu, mengingat bahwa penelitian ini terbatas pada 14 siswa sebagai subjek penelitian, maka studi eksperimental dengan jumlah subjek yang lebih besar dapat dilakukan untuk memverifikasi keandalan strategi pembelajaran yang diterapkan dalam penelitian ini.

\section{DAFTAR PUSTAKA}

Bagiati, A., \& Evangelou, D. 2016. "Practicing Engineering While Building with Blocks: Identifying Engineering Thinking." European Early Childhood Education Research Journal 24(1):67-85.

Barroso, L. R. et al. 2016. "Using the Engineering Design Process as the Structure for Project-Based Learning: An Informal STEM Activity on Bridge-Building." IEEE Integrated STEM Education Conference (ISEC), 249-56.

Baser, D., Ozden, M. Y., \& Kaarslan, H. 2017. "Collaborative Project-Based Learning: An Integrative Science and Technological Education Project." Research in Science \& Technological Education 35(2):131-48.

Bell, Stephani. 2010. "Project-Based Learning for the 21st Century: Skills for the Future." Journal of Educational Strategies 83(2):39-43.

Chin, C., \& Chia, L. G. 2005. "Problem-Based Learning: Using Ill-Structured Problems in Biology Project Work." Science Education 90(1):44-67. 
George Lucas Educational Foundation. 2007. Project-Based Learning.

Griffin, P., McGraw, B., \& Care, E. 2015. Assessment and Teaching of 21st Century Skills Methods and Approach. Dordrecht: Springer.

Guzey, S. S., Moore, T. J., Harwell, M., \& Moreno, M. 2016. "STEM Integration in Middle School Life Science: Student Learning and Attitudes." Journal of Science Education and Technology 25(4):550-60.

Häkkinen, P., Järvelä, S., Mäkitalo-Siegl, K., Ahonen, A., Näykki, P., \& Valtonen, T. 2016. "Preparing Teacher-Students for Twenty-First-Century Learning Practices (PREP 21): A Framework for Enhancing Collaborative Problem-Solving and Strategic Learning Skills." Teachers and Teaching 23(1):25-41.

Han, S., Capraro, R., \& Capraro, M. 2014. "HOW SCIENCE, TECHNOLOGY, ENGINEERING, AND MATHEMATICS (STEM) PROJECT-BASED LEARNING (PBL) AFFECTS HIGH, MIDDLE, AND LOW ACHIEVERS DIFFERENTLY: THE IMPACT OF STUDENT FACTORS ON ACHIEVEMENT." International Journal of Science and Mathematics Education.

Hernandez, P. R., Bodin, R., Elliott, J. W., Ibrahim, B., Rambo-Hernandez, K. E., Chen, T. W., \& de Miranda, M. A. 2014. "Connecting the STEM Dots: Measuring the Effect of an Integrated Engineering Design Intervention." International Journal of Technology and Design Education 24(1):107-20.

Hesse F. W., Care, E., Buder, J., \& Griffin, P. 2015. "A Framework for Teachable Collaborative Problem Solving Skills." in Assessment and Teaching of 21st Century Skills. Educational Assessment in an Information Age. Springer, Dordrecht.

Hong, J. C., Chen, M. Y., Wong, A., Hsu, T. F., \& Peng, C. C. 2012. "Developing Physics Concepts through Hands-On Problem Solving: A Perspective on a Technological Project Design." International Journal of Technology and Design Education 22(4):473-87.

Kemendikbud. 2017. Model Silabus Mata Pelajaran Sekolah Menengah Pertama/Madrasah Tsanawiyah (SMP/MTs) Mata Pelajaran Ilmu Pengetahuan Alam. Jakarta: Kementrian Pendidikan dan Kebudayaan.

King, D., \& English, L. D. 2016. "Engineering Design in the Primary School: Applying Stem Concepts to Build an Optical Instrument." International Journal of Science Education 38(18):2762-94.

Laboy-Rush, D. 2010. Integrated STEM Education through Project-Based Learning.

Lai, E., DiCerbo, K., \& Foltz, P. 2017. "Skills for Today: What We Know about Teaching and Assessing Collaboration." London: Peason.

Loeb, S., Dynarski, S., McFarland, D., Morris, P., Reardon, S., \& Reber, S. 2017. Descriptive Analysis in Education: A Guide for Researchers. (NCEE 2017-4023).

Marulcu, I., \& Barnett, M. 2016. "Impact of an Engineering Design-Based Curriculum Compared to an Inquiry-Based Curriculum on Fifth Graders' Content Learning of Simple Machines." Research in Science \& Technological Education 34(1):85-104.

Moje, E. B., Collazo, T., Carrillo, R., \& Marx, R. W. 2001. "'Maestro, What Is Quality?': Language, Literacy, and Discourse in Project-Based Science." Journal of Research in Science Teaching 38(4):469-98. 
Schnittka, C. G., Evans, M. A., Won, S. G. L., \& Drape, T. A. 2016. "After-School Spaces: Looking for Learning in All the Right Places." Research in Science Education 46(3):389-412.

Susanti, N. A., \& Kurniawan, W. D. 2020. "PENERAPAN MODUL CNC I MENGGUNAKAN PEMBELAJARAN BERBASIS PROYEK UNTUK MENINGKATKAN AKTIVITAS DAN HASIL BELAJAR MAHASISWA TEKNIK MESIN UNESA." Journal of Vocational and Technical Education (JVTE) 2(2):45-53.

Wendell, B. K., \& Rogers, C. 2013. "Engineering Design-Based Science, Science Content Performance, and Science Attitudes in Elementary School." Journal of Engineering Education 102(4):513-40.

Wicaksono, A. G. (2020). Penyelenggaraan Pembelajaran IPA Berbasis Pendekatan STEM dalam Menyongsong Era Revolusi Industri 4.0. Lensa (Lentera Sains): Jurnal Pendidikan IPA, 10(1), 54-62.

Yanyan, L., Zhinan, H., Menglu, J., \& Wen, C. T. 2016. "He Effect on Pupil's Science Performance and Problem-Solving Ability through Lego: An Engineering DesignBased Modeling Approach." Journal of Educational Technology \& Society 19(3): 143-56. 